\title{
The Present Dynamics of Financial Risks Related to Macroeconomic Policies in Oecd Countries, and Business Cycles
}

\author{
A. Niyazi Özker \\ Department of Public Finance, Faculty of Economic and Business Administration, Bandırma Onyedi Eylül University, Turkey
}

Copyright $\bigcirc 2017$ by authors, all rights reserved. Authors agree that this article remains permanently open access under the terms of the Creative Commons Attribution License 4.0 International License

\begin{abstract}
In this study, we aim to attempt to analysis the effects of financial risks on the shaping of macro-economic policies that directly touch with business cycles in OECD countries. As known, the public liabilities with financial budget deficit fact, as a concept of financial risk element, is an important phenomenon that affects on all the whole other financial and economic balance dynamics in the developed economies as well as less developed countries. In this point, the financial risks leaned on the consolidated central government budget put forth to meaningful financial deficits interested in the global integrations and its measurement matter of deficits in the same process, which aim to directly analysis macroeconomic policies. First, the priority effect of financial risks based on the budget deficits is appeared on the harmonization of monetary with fiscal policies as macroeconomic politics, and this concept has been an important financial matter especially in developing countries toward to determine macro elements. Second, these effects should be questioned for ensuring stability of economic in the business cycles related to GDP together with the business cycles related to financial liabilities in OECD countries. In this context, the effects of financial risks should be considered in two structural balances terms related public budget as budget surplus and deficits aimed at macroeconomic policies dynamics that also means correlation among these concerned financial dynamics. Thirdly, it is related to the location in public decision making process of these effects. Actually, on the other hand this situation reflects the effects of financial liabilities as a foundation stone on public decision making process that should need monetary liabilities like contend with probably inflation ensured.
\end{abstract}

JEL Classification Numbers: H11; H53; H62; H68.

Keywords Financial Risk, Macroeconomics Policies, Financial Liabilities, Business Cycles, Public Decision Making Process

\section{Introduction}

The financial risks touch with public budget deficits were considered as only part of fiscal position in the each country for a long time in where its financial effects were ignored in the same process [2]. However, in nowadays it is eventually that the budget effects have global macroeconomics features as well as being financial concept those meaningful financial liabilities with its structural dept levels [7]. Composite indicators can present the macroeconomic growth net values debt levels as a percent of GDP. In addition, also exchange risks and foreign payments balances risks can be related to central budget deficits within macroeconomic performance, which mean the implications of financial liabilities central public budget in practice. But, the related to risks of international dimension in the global ground that are in the inevitable position as a result of globalization process have an important role on the fiscal policy making decision process [6].

Especially in OECD countries these concerned financial values that are related to financial liabilities put forth as a financial budget phenomenon, and that should be considered together with monetary policies to analyze the relationship of budget deficits and macroeconomic evaluations in each other. In addition, this financial fact causes a lack of harmony between monetary options and interest rates via the increasing rates of interest that take on the financial burden for budgeting as financial liabilities. In this point, it appear that budget deficits need more monetary liquidity via increasing monetary supplies rather than increasing investments budget-based implications [10]. However, it should be unforgotten point is that public budget surplus also have effects on business cycles as well as probably budget deficits due to present correlations 
business cycles budget-based as the component of financial liabilities. In other words, all the financial liabilities dimension of public budget deficits is a seriously burden to the sectoral business circular reasoning along the macro deviational dynamics [12]. The structural importance of financial liabilities comes to scene exactly in this point directed toward general government debt securities [12]. But still, the budget components like tax revenues options have the most importance for financing budget deficits, but especially much more increasing in developing countries creating fiscal obligation in OECD countries. Of course macroeconomic policies are constituted by various structural policies but not with only economic and financial policies which means these policies should be considered with the exception of social politics' goals [19]. So, the analysis of macro financial liabilities related directly to budget deficits, especially taxation options should be certainly evaluated together with social dimensions that put forth financial burdens within the macroeconomic policies making process in the spite of differential risk dimensions in OECD countries [12].

\section{The Main Dynamics of Financial Risks for OECD Countries}

The main risk factors can be defined via the budget deviations of countries in both general and specific context related to their own improvement process. It should be emphasized that the main risk factors can generally be in two structural terms that present the fiscal bias crisis dynamics and then bank financial operations options [21]. If the some specific dynamics take place in the crisis process as the risk of banks liabilities, the public financial liabilities can effective role on the approach of banks risk arrangements to cope with financial crisis, and which is possible to find much more examples in OECD countries [15]. Figure 1 expresses these main risk factors in OECD countries together with specific factors like demographic issues below [5]:

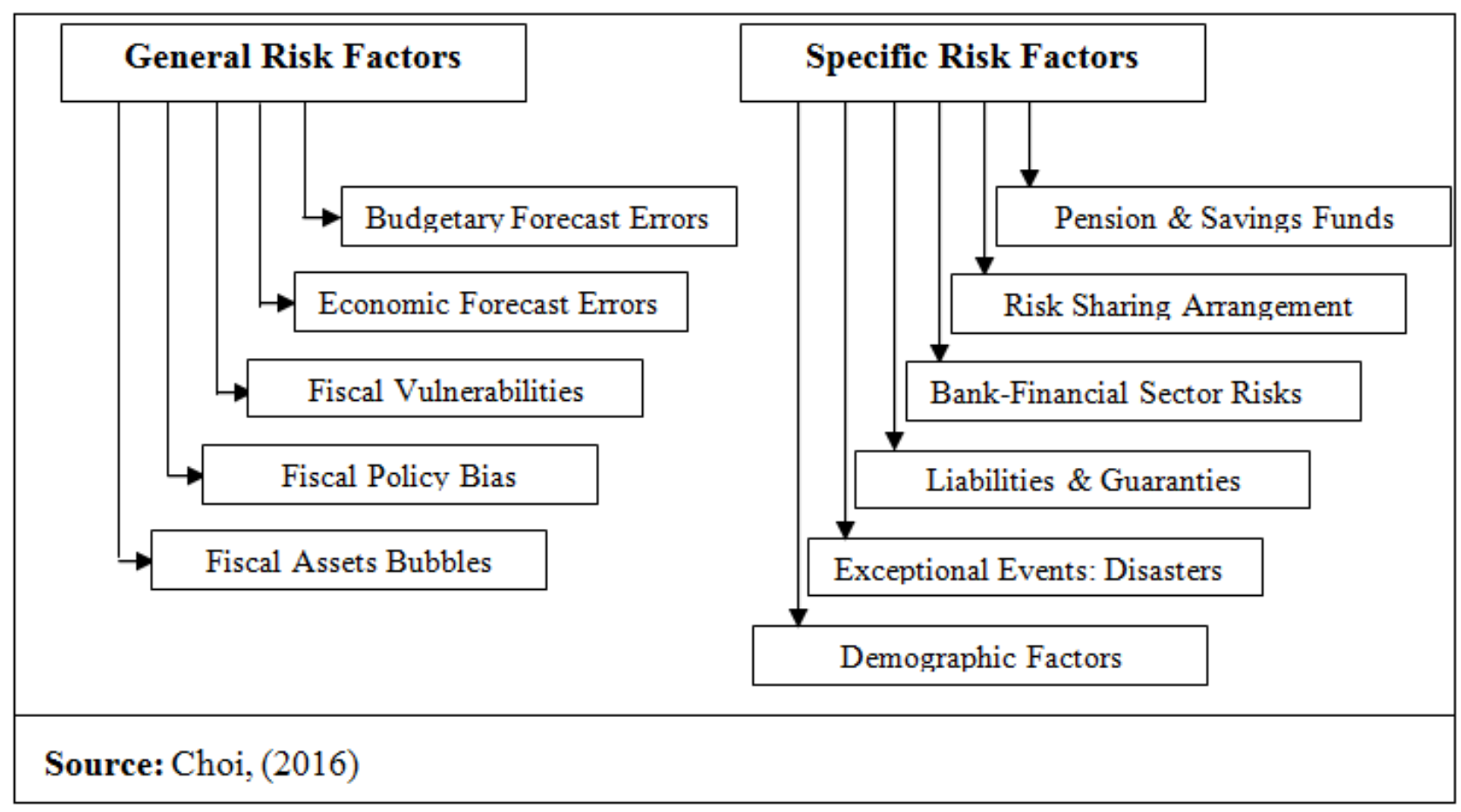

Figure 1. The Main Risk Factors in OECD Countries 


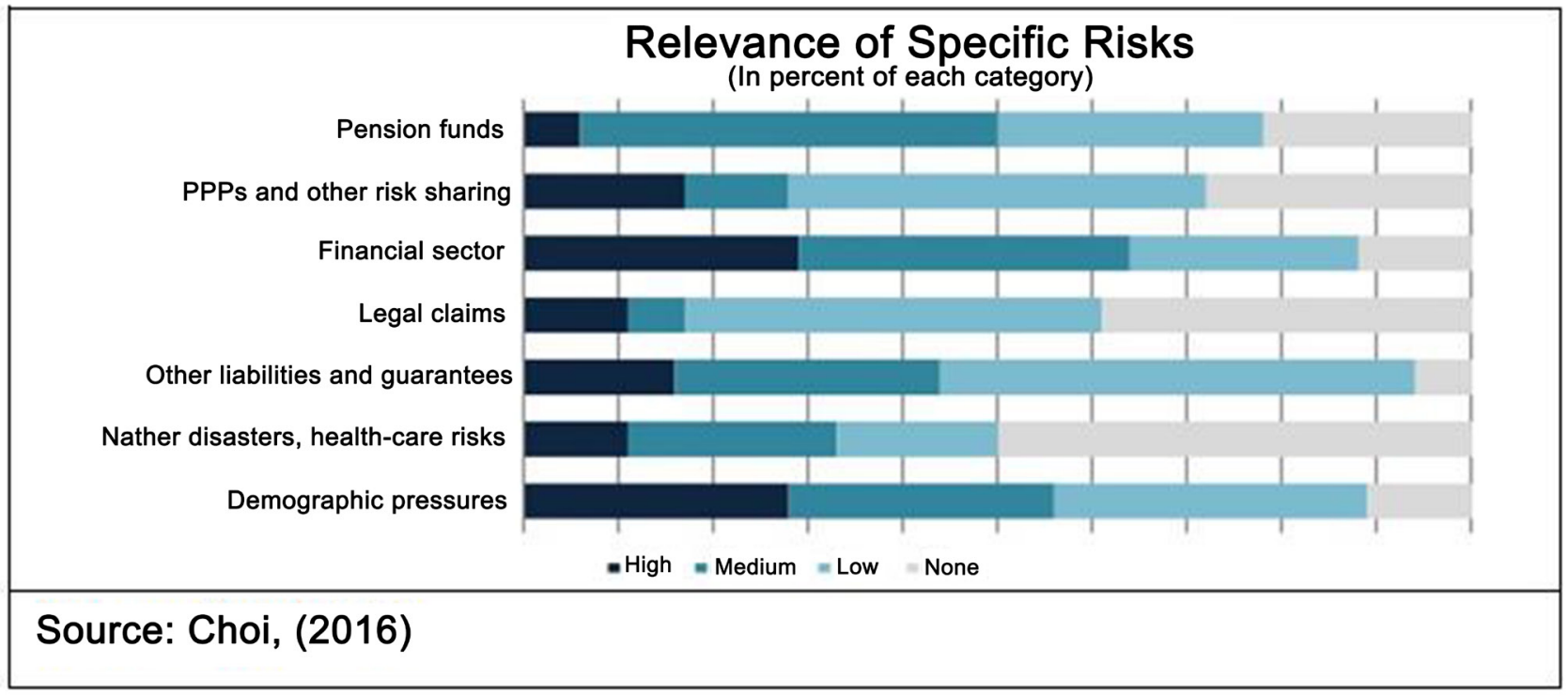

Figure 2. The Proportional Distribution of Specific Financial Risk Factors

As seen on figure 1, although these countries have the important range of financial deficits related to financial crisis, in many cases, the reason of this situation is the indicators of financial openness used by expertise's have the forecast errors toward public revenues in OECD countries [2]. In other cases related to public budgetary location can be said that the most of OECD countries have been in negative trade trend that mean to ascertain the link between trade policy and growth have serious shortcomings toward to support public budget [15].

Therefore it should be forgotten this financial context is directly touch with directly banks and the other probably some financial crises because of the financial infrastructure come into being in the scope of the macro financial options, but except for public transactions as a the bigger criteria [1]. In OECD countries, this structural location related to financial crises have been in the controlling of developed countries like USA, Canada, France, Germany, Japan and United Kingdom that have largely financial liabilities in OECD group for a long time. Therefore, it make not a mistake expressive that financial crises from that based on origin these developed countries make more trouble for the other OECD countries due to these countries experience the main priority dynamics of financial crises [15].

\section{The Specific Financial Risks and Their Dynamics}

This specific dynamics of fiscal crises can identify five term topics as key cross-cutting public governance issues that crisis management policies and practices should pay attention to governance framework, leadership, the governance of networks, and international cooperation. In this point, financial sector is in the locomotive location of crisis period due to its manipulation the other liabilities and guaranties in legal financial claims [15]. As considering dynamics with their own structural on financial risks is one of OECD's objectives, these considered specific areas can contribute into the development of principles on crisis management. Figure 2 expresses the specific risk dynamics in percent each specific category in OECD countries.

These dynamics in Figure 2 express also how to ensure something does this require contributing crisis management to adapt their approaches with their tools in various areas of crisis management towards more flexibility in their concerned scope. Because some crisis factors are on exceed the upper of less developed countries, these countries both they cannot be in responsibility and not be blamed accusing for financial crises [20]. The financial applications of government in openness and transparency widespread dissemination of information on-electronic line put governments and their decision-makers under constant pressure as related to the financial management in the developed countries [2]. Furthermore, these less developed countries in OECD ensure not responsibility in the high standards of ethics from their government even if their own specific risk factors [14]. In addition, global factors related the other liabilities and guaranties for other countries should not be forgotten because of these have increasingly been highlighted as important special risk determinants of all the countries risk spreading [14].

\section{Today's Structural Responsibilities for Managing to the Financial Risk Dynamics}

Financial risk responsibilities can be defined as the maximum sensitivity taking decision making of uncertainty fact in making a financial decision process. In this context, financial risk managing that include has some important responsibilities related to today's structural dynamics. In this framework, structural financial responsibilities can be considered below: 
- The Technical Infrastructure of Economic Functions Directed to The Financial Responsibility: Calculating fiscal balances especially related to central public budget means to be required macro functions-based forecasting for analyzing in today's fiscal dynamics. Therefore, in the other words in all macroeconomic operations and cases, the pattern of association between socioeconomic factors that are affected via speculative approaches and financial risk tolerance is equivalence to the expected macroeconomic responsibilities and this fact shape macro financial responsibilities [15].

- The Politic Accountability and Accounts' Explanation in Civil Publically Units: Public opinion generally desire to obtain information about the future of financial balance components shaped in the macroeconomic-based units. This higher responsibility component that ensure with higher levels of financial knowledge is the result of the Politic Accountability and Accounts' Explanation in Civil Publically Units required. Also the Politic Accountability and Accounts' Explanation in Civil Publically Units required is today's indispensable democratic feature [18].

- The Need to Know of Financial Policy Costing and Its sharpness: The financial inform and its structural importance to ensure the desired macroeconomic-based aims is the topic of debate in between politics and politicians. But, it should be forgotten that the costing financial policy cate with financial risk tolerance is a complicated process that goes beyond the exclusive use of socioeconomic factors containing also the other social costs [3].

- Fiscal Watchdog and Its Observations' Effects: Fiscal observations' effects express the today's fiscal responsibilities originating from the main desired macro financial politics. The responsibility for watchdogging the financial position is the key point of financial risk management in public practice and unfortunately this structural phenomenon is the most incomplete component especially in fewer developing countries for managing risk period [4].

- Policy Advice directed towards the Risk Management, and Its Expectations from Today to Future: Policy advice directed towards the risk management means the revised financial risk management in public decision making process to future. On the other hand, if the fiscal advice subjects have not able to truly guessed considering at the purpose of the financial aims, especially the less developing countries will be able to none guessed the true purpose of the financial responsibilities in today [8].

\section{The Location of Fiscal Liabilities in OECD Countries as a Fiscal Risk Dynamic}

In general a review, the concept of financial liabilities expresses the transfer of public financial assets as a cash payment approach including debts transferring. Among OECD countries, especially these more important developed countries that are Canada, France, Germany, Japan and United Kingdom have financial liabilities, and they are virtually in locomotive position to the other countries of OECD. But China is not member of OECD in spite of it has the meaningful level of financial liabilities with its remarkable economic growth levels. Table 1 shows financial liabilities as a per cent of GDP.

As seen on table 1, the financial liabilities reserve a place importance in GDP of OECD countries led to the financial obligations especially being debt options in each other's. This situation can be commented in two points of views. First, the location of economic growth levels should be considered comparing to their financial liabilities in OECD countries. Some OECD countries can prefer to catch the desired economic growth with probably higher financial liabilities than other OECD countries that have financial options. As toward to verifying this thesis China that is not a member of OECD can be taken a good example to OECD's financial obligations for analyzing matter. In other words, China has been within its approach in the present own equity instruments that probably will be settled other than differences of OECD. So, it has not been in economic deviation through the exchange of cash or similar for a fixed amount for a long time, and contrary it has been in fairly higher economic growth process, not affected by financial liabilities. Second, currency has effected negatively on the alteration of exchange rates because of some countries' currency not strong according to some countries that have more strong currency especially in less developed countries. The reason of this financial location is the more financial fragilities tendency of less developed countries than the more developed countries, which means there is not homogeneous distribution of financial burden in OECD countries [16]. 
Table 1. Financial Liabilities (Gross) in OECD Countries and World as a \% GDP

\begin{tabular}{|c|c|c|c|c|c|c|}
\hline & & 2012 & 2013 & 2014 & 2015 & $\begin{array}{l}\% \text { of World } \\
\text { GDP } \\
\end{array}$ \\
\hline & (A) & (B) & (C) & (D) & (E) & (F) \\
\hline 1. & Canada & $96.1 \%$ & $97.0 \%$ & $97.1 \%$ & $96.6 \%$ & $2.4 \%$ \\
\hline 2. & France & $109.3 \%$ & $113.0 \%$ & $115.8 \%$ & $116.9 \%$ & $4.3 \%$ \\
\hline 3. & Germany & $88.3 \%$ & $86.1 \%$ & $83.4 \%$ & $80.9 \%$ & $5.8 \%$ \\
\hline 4. & Japan & $218.8 \%$ & $227.2 \%$ & $231.9 \%$ & $235.4 \%$ & $8.8 \%$ \\
\hline 5. & $\begin{array}{c}\text { United } \\
\text { Kingdom }\end{array}$ & $102.4 \%$ & $107.0 \%$ & $110.0 \%$ & $111.6 \%$ & $4.5 \%$ \\
\hline 6. & United States & $102.1 \%$ & $104.1 \%$ & $106.3 \%$ & $106.5 \%$ & $25.5 \%$ \\
\hline 7. & $\begin{array}{c}\text { OECD } \\
\text { Euro area } \\
\text { (15 countries) }\end{array}$ & $104.3 \%$ & $106.4 \%$ & $107.1 \%$ & $106.8 \%$ & $26.0 \%$ \\
\hline & & & & & & \\
\hline 8. & China (est.) & & & & $160 \%$ & $\mathbf{8 . 0} \%$ \\
\hline
\end{tabular}

Source: OECD (2016)

\section{The Level of Common Relationship of Fiscal Liabilities with Business Cycles Access}

Fiscal liabilities evolves to accommodate changes in accountable of business cycles and budget balances are generally strongly financial cyclical in aimed to during times of strong GDP via ensuring the effect levels of financial liabilities. However it should be forgotten that the financial investors in the business world take of risk dynamics in business cycles process based on the limited traditional financial locations in crisis period. In this context, it can express that the financial fact contains the four main parts [17]:

- The Revival of Business Cycles Dynamics that are related to Fiscal Liabilities

The conditions at beginning of business world shape the perspective of business cycles towards financial liabilities in the scope of revival. Macro financial deficits have been high during the financial crisis and recession, namely the 2008 and after, recessions in the spite of increasing favorable outlook for investment constructing in business world. In this context accumulated shortage of real goods that cause financial liabilities has been the most important phenomenon. In addition, in the point this fact gives a direction the increasing prospect of markets stimulators forward to investments considering also global financial liabilities [9].

- The Desired Prosperity in the Framework of Improvement Business Cycles

Improving business cycles express to also analysis the desired prosperity together with economic growth process in the scope of financial risk dynamics. If the all the business costs fall off, production costs fall out in production process and stocks of goods become larger in market overbought. The prosperity that related to the consuming levels will increase equivalent, consequently national welfare will increase via the fall off factorial costs. In this point, financial liabilities come to mean costs in business cycles, and each financial liability item creates deviation to the desired prosperity.

- The Liquidations in the Business Cycles related to Investment Process

The liquidations in the business require especially for investment process, which cause differences on the prices. The liquidations in the business are required for ensuring balances between business cycles and different prices formation. In the crisis period, the liquidation in business cycles is located in micro sectoral dynamics and its structural consequences put to decline prices more rapidly. Consequently, the increased financial liabilities cause to increase sectoral costs as a result of increasing credit spread, that most meaningful reason of liquidations [11].

- The Financial Depressively Attitude in the Business Cycles Process

Financial attitude in the business cycles can be in a generally depressively location as a credit strain reduced in crisis process. In this way, financial depression process begins to be transformed to into prosperity dynamics. In middle and long-term period construction costs decline and money supply politics into reduce the size in application process. Consumers and merchants tend to gradually accumulate the economic goods together with consuming goods to keep their previous prosperity in the output process of depression [13].

\section{Conclusions}

All the present dynamics of financial risks related to macroeconomic policies especially in OECD countries can be considered in the two main terms that its structural responsibilities to probably financial crisis dynamics and 
second, financial liabilities that directly effect on business cycles. But, that should be paid attention to structural differences in developing countries that are member of OECD that their different responsibility levels towards to perceive financial risk factors. In this context, effective capital accumulation (or sufficient capital accumulation) is the most meaningful way in business cycles to overcome global risk criteria. But provided that budget deficits that also include to application of taxes and public expenditures can reflect on the fiscal policy decisions about business cycles consisting the monetary items of policy.

A compelling in business cycles reason to be concerned about financial risk factors should be accept is that public debt, like all types of borrowings, has to be considered in business cycles. Financial liabilities in business cycles as interests and amount borrowed, need to be reconstructive to avoid add borrowings costs as increasing fiscal costs. The aim is in this point to ensure macro financial balances. But sometime the financial policies lose the effect of applications in OECD countries due to these countries have different criteria effects on financial transactions that means to put forth to inevitable deviations. It is understood that financial risk factors, especially in developing countries, it cannot acceptable in the location of increasing financial deficits toward to ensure to prevent wavy integrations that cause financial instability in unbalances business cycles. From this perspective sometime budget surplus or deficits should be highly correlated with the business cycles.

\section{REFERENCES}

[1] Ahrend, R., Cournede, B. and Price, R. (2008), Monetary Policy, Market Excesses and Financial Turmoil, Economics Department Working Paper No. 597, OECD 2008.

[2] Baibuon, C. (2014), OECD Risk Management: Strategic Crisis Management, OECD 2013.

[3] Benigno, G., Chen, H., Otrok, C., Rebucci, A. and Young, E.R. (2011), Financial Crises and Macro-Prudential Policies, Inter-American Development Bank (IDB) Working Paper Series No. IDB-WP-238, Washington D.C.: Inter-American Development Bank, 2011.

[4] Calmfors, L. (2011), The Role of Independent Fiscal Policy Institutions, Institute for International Economic Studies Seminar paper No. 767, Stockholm: University and Swedish Fiscal Policy Council, Institute for International Economic Studies, 2011.

[5] Choi, J. (2016), Fiscal Risks in OECD Countries: Identification, Management and Mitigation, Retrieved March 11, 2017, fromhttps://www.slideshare.net/OECD-GOV/fiscal -risks-in-oecd-countries-identification-management-and-miti gation-jaehyuk-choi-oecd-secretariat
[6] Crotty, J. (2008), Structural Causes of the Global Financial Crisis: A Critical Assessment of the New Financial Architecture, University of Massachusetts Economics Department Working Paper Series 2008-14, 1-61.

[7] Cumming, C. M. and Hirtle, B. J. (2001), "The Challenges of Risk Management in Diversified Financial Companies", Federal Reserve Bank of New York Economic Policy Review, $1-17$.

[8] Darley, W. K. and Smith, R. E. (1995), "Gender Differences in Information Processing Strategies: An Empirical Test of the Selectivity Model in Advertising Response", Journal of Advertising, 24(1), 41-56.

[9] Fidrmuc, J. and Korhonen, L. (2009), The Impact of the Global Financial Crisis on Business Cycles in Asia Emerging Economies, BOFIT Discussion Papers 11/2009, Helsinki: Bank of Finland, Institute for Economies in Transition, 2009.

[10] Folkman, P., Froud, J., Johal, S. and Williams, K. (2007) "Working for Themselves?: Capital Market Intermediaries and Present Day Capitalism," Business History, 49 (4), (July 2007), 552-572.

[11] Iacoviello, M. (2005), "House Prices, Borrowing Constraints, and Monetary Policy in the Business Cycle," American Economic Review, 95(3), 739-764.

[12] ILO - International Labor Organization (2011), The Global Crisis: Causes, Responses and Challenges, Geneva: International Labor Office, 2011.

[13] Jaimovich, N., and Rebelo, S. (2008), "News and Business Cycles in Open Economies," Journal of Money, Credit and Banking, 40(8), 1699-1711.

[14] Lim, G. C., Claus E., Nguyen V. and Chua M. (2013), Budget Deficits, Business Cycles and Macroeconomic Policies, Melbourne Institute Policy Brief No. 5/13, Melbourne: Melbourne Institute of Applied Economic and Social Research, August 2013.

[15] OECD (2014), Risk Management and Corporate Governance, OECD 2014.

[16] OECD (2016), Economic Outlook: Statistics and Projections Database, OECD 2016.

[17] OECD (2017), Retrieved March 13, 2017, from http://www.oecd.org/std/fin-stats/

[18] Rhodes, A.W. (1997), Understanding Governance: Policy Networks, Governance, Reflexivity and Accountability, Philadelphia: US, Open University Press, 1997.

[19] Stiglitz, J. E. (2010), "Lessons from the Global Financial Crisis of 2008", Seoul Journal of Economics, 23(3), 321-340.

[20] Turner, B. (2014), The Statement's Yearbook 2015: The Politics, Cultures, and Economies of The World, London: Macmillan Publishers Ltd., 2014.

[21] Wipplinger, E. (2007), "Philippe Jorion: Value at Risk - The New Benchmark for Managing Financial Risk", Fin Mkts Portfolio Mgmt. Book Review (21), Swiss Society for Financial Market Research, 397-398. 